\title{
Co nám přinesla Boloňa?
}

Vážení čtenáři,

od podpisu Boloňské deklarace uplynulo v letošním roce již třináct let. Pokud čteme cíle, které za touto deklarací a navazujících dokumentů stály, nelze jim upřít snahu o rozvoj vysokého školství v Evropské unii. I po třinácti letech však zůstává otázkou, zdali cesty, na kterých je celý tento proces založen, jsou takové, že k těmto cílům povedou.

Nelze v krátkém textu rozebrat detailně všechny oblasti, které byly Boloňskou deklarací ovlivněny, zkusme se podívat spíše právě na základní filozofii, na níž je celý proces založen, a posoudit nejviditelnější dosažené výsledky.

Oficiální dokumenty většinou - přes dílčí problémy - zdůrazňují významný pokrok, kterého bylo dosaženo. „Z téměr exkluzivně národních systémů vysokoškolského vzdělávání, které se lišily strukturou studia a jejichž studijní programy bylo obtižné porovnávat ... se podařilo vytvořit systém národních systémů s poměrně harmonizovanou architekturou studia řšenou ve třech stupních - bakalářském, magisterském a doktorském. "1. Toto hodnocení poměrně jasně ukazuje, jakým směrem se boloňský proces zejména ubíral - sjednocování struktury vysokoškolského vzdělávání a principů, na kterých je postaveno. Statistikům pro sledování to možná život ulehčilo, ale nezodpovězenou otázkou zůstává, zdali tento proces přispěl k rozvoji a vyšší kvalitě vysokého školství v Evropě. Ani v nejmenším nechceme zpochybňovat rozvoj mezinárodní spolupráce vysokých škol a významný nárůst studentských výměn, $\mathrm{k}$ němuž $\mathrm{v}$ uplynulém období došlo. Nicméně se $\mathrm{v}$ tomto směru poněkud přeceňuje význam formálního sjednocování vysokoškolského studia. I poslední diskuse nad rozpočtem Evropské unie ukazují, že např. pro rozvoj studentských výměn je klíčová finanční podpora a ,jednotný“ kreditový systém je až na druhém místě.

Je třeba si totiž uvědomit, že ono sjednocení národních systémů se odehrálo ve formální rovině nikterak $\mathrm{v}$ rovině věcné. A tak přesto, že máme jednotné tři stupně studia, evropské kredity, vymýšlíme shodné kvalifikační rámce atd., výsledkem není a ani nemůže být stejná úroveň škol, stejná náročnost studia, stejný obsah apod. A v tomto kontextu někdy až přehnaná snaha o formální sjednocení je nejen zbytečná, ale může i odvádět pozornost právě od těch podstatných obsahových záležitostí. Formální sjednocení nikdy nebude znamenat sjednocení reálné. Není problém např. formálně sjednotit obsah určitých předmětů. Ale to nikdy nebude znamenat, že kdokoli a kdekoli takový předmět absolvuje, bude mít shodné znalosti. Vždy bude záležet na tradici školy, osobnosti učitele, motivaci a konkurenci mezi studenty atd. Proto bude výsledek vždy reálně jiný byt', formálně stejný.

Namísto snah o formální sjednocování by se spíše více pozornosti mělo proto věnovat tomu, jak získat informace o obsahu a kvalitě té které školy, jak porovnat jejich skutečnou úroveň, jak propojovat odlišné systémy. Sjednocování musí probíhat z toho důvodu a tam, kde k němu bude tlačit konkurence mezi školami. Pokud se některé modely ukážou jako životaschopnější, budou je jiní následovat. Není přeci cílem mít unifikované vysoké školy, nýbrž přes vzájemnou konkurenci tlačit na jejich další rozvoj. A právě určitá specifičnost a originalita té které vysoké školy je tím, co může být tahounem kvality a rozvoje vysokoškolského vzdělání.

1 Viz MŠMT ČR: Boloňský proces. [on-line], Praha, Ministerstvo školství, mládeže a tělovýchovy České republiky, c2012, [cit. 10. 6. 2012], <http://bologna.msmt.cz>. 
Asi nejviditelnějším výsledkem boloňského procesu u nás bylo zavedení třístupňového studia doprovázeného pyramidovou strukturou počtu studentů $\mathrm{v}$ jednotlivých stupních. Co nám přinesla? Nárůst počtu bakalářů, které školy vypouštějí, ač jsou si vědomi, že potřebná část studia se jim již nedostane, a naše praxe stále není ochotna je v plné míre akceptovat. Představy o migraci studentů mezi bakalářským a navazujícím magisterským studiem mezi různými školami se naplňuje jen velmi, velmi málo. Systém kvót pro počty bakalářských a magisterských studentů neumožňuje školám se profilovat výrazněji na magisterské studium, a tak důvody a vůbec možnost přejít na navazující magisterské studium na jinou školu mnoho není. Rovněž tak úvahy o tom, že do navazujícího magisterského studia budou nastupovat bakaláři třeba po několika letech strávených v praxi, byl od samého počátku velmi pochybný (čím delší odstup od bakalářského studia, tím těžší je zvládání náročnějších magisterských předmětů, zahajovat magisterské studium „, pokročilejším věku“ je těžko schůdné i z finančních důvodů, opustit zaměstnání a vrátit se ke studiu je změna stylu života, po které po několika letech $\mathrm{v}$ praxi málo kdo touží...). Rozdělení na bakalářské a navazující magisterské studium tak přineslo další administrativní zátěž pro školy, ale reálný přínos pro rozvoj kvality vysokého školství či pro samotné studenty zůstává poněkud utajen.

Pro budoucnost Evropy bude školství včetně vysokého velmi důležité, pokud se budou mít možnost potkávat studenti, učitelé, vědci může to mít mimo jiné významný vliv na posilování vnímání sounáležitosti s Evropou, která se dnes spíše drolí. Cesta však nevede přes nákladné formální sjednocování, které často svou byrokratičností spíše odrazuje, nýbrž přes posilování autonomnosti a originality škol, které si nejefektivnější formy a způsoby spolupráce při rostoucí konkurenci v oblasti vzdělávání určitě najdou.

doc. Ing. Petr Dvořák, Ph.D.

děkan Fakulty financí a účetnictví

Vysoké školy ekonomické v Praze 